\title{
STUDY OF THE HISTORY AND DYNAMICS \\ OF THE AGRARIAN POLICY IN TRANSFORMING \\ THE INDONESIA'S AGRARIAN REFORM
}

\author{
Triana Rejekiningsih; Chatarina Muryani; Diana Lukitasari \\ Faculty of The Teacher Training and Education, Universitas Sebelas Maret \\ E-mail: triana_rizq@staff.uns.ac.id
}

\begin{abstract}
This study was conducted to find out: (1) the agrarian history as a milestone of the agrarian policy in Indonesia; (2) the dynamics of agrarian policy as a driving factor for the agrarian reform; (3) agrarian policy as a means of transforming the agrarian reform in Indonesia. This study is a normative juridical legal research with a historical approach, in addition to use conjunctural approach to examine the complex, historically specific, of various agrarian policies. The study concludes that: (1) Agrarian history is an important part of the agrarian policy realization, beginning from Dutch colonialism along with the dominated agrarian resources and the raise of peasant resistance against imperialism, this condition gave rise to the spirit of national movements and the birth of Law Number 5 of 1960 on The Agrarian Basic Law (hereinafter abbreviated to UUPA) as the basis for agrarian policy in Indonesia; (2) Not all the agrarian policies are oriented towards the objectives of the UUPA, often time they cause problems in their application, among others its irrelevant to principles of justice and people's welfare, land tenure disintegration, lack of certainty over the land rights, stand for the capital owners, opening up of foreign investors controlling agrarian sources, the designation of forest areas on people's lands, nationalization of the plantations, repressive resolution of agrarian conflicts, and land certification which legalizes inequality land tenure structures; (3) agrarian policy is an important part of the process of realizing the agrarian reform, especially in the context of agrarian transformation towards the formation of a 'agrarian' society structure integrated into economic pillars to improve people's welfare.
\end{abstract}

Key Word: history, policy, transformation, reform, agrarian

\section{INTRODUCTION}

The history of the Indonesian Nation shows that agrarian issues have not been placed as the main concerns to be resolved. Especially in the current condition of the nation afflicted by a multidimensional crisis, then it is very appropriate to discuss a very complicated agrarian problem. According to Gunawan Wiradi, an agrarian expert who legitimated an imperative theorem, that in a time of crisis the Indonesian nation was in dire need of agrarian reform, or it is a must (imperative) to be faced by

Yustisia Volume 8 Number 2 (May-August 2019)

Study Of The History And ...

309

(C)2019; This is an Open Acces Research distributed under the term of the Creative Commons Attribution Licencee (https://Creativecommons.org/licences/by/4.0), which permits unrestricted use, distribution, and reproduction in any medium, provided the original works is properly cited. 
the Indonesian nation at the present time. Bearing the agrarian reform is part of the complicated things to do, it is highly significant to be the main concerns to realize (2009: xxxii).

The urgency of agrarian reform is to overcome inequality in exploring the agrarian resources, agrarian conflicts, environmental damage, and to overcome poverty. Data announced by The Central Bureau of Statistic (hereinafter abbreviated to BPS in early 2014, there is an imbalance in ownership of land resources from 0.32 in 2004 to 0.41 in 2013 (Hadi Daryanto, 2014: 1). Agrarian reform in its application should pay attention to two objectives, among others: (a) working for social transformation, and (b) dealing with social conflicts to reduce future conflicts possibility (Wiradi, 2003: 3). Wiradi (2009: 194) suggested that the nature of agrarian reform lies in its rearrangement or renewal of the ownership structure, control and use of land / territory intended for small farmers' interests, rubber tappers, and landless farm laborers. The success of agrarian reform determined by holistic indicators understanding related to agrarian problems obtained from critically conducted research. It is quite substantially important to recognize various agrarian problems as a result of the policy, which is where the starting point is as an effort to improve the agrarian policy implemented in the future. The dynamics of agrarian policy occurred in Indonesia are closely related to the agrarian history arose during to the ruling regime. Since the era Oost-Indische Compagnie (VOC), in 1602 to the post-Independence Republic of Indonesia, from the regime era of President Soekarno to President Joko Widodo. The successful context of agrarian reform policies lies in the succeeding factors, namely the availability of complete and accurate data on diagramming. In the context of preparing agrarian reform, diagramming data, more especially the agrarian policies is highly required. Thus, it needs a study-oriented investigation which concerns the exploring the agrarian history and agrarian policies in implementing the agrarian reform.

The effort made to examine the agrarian milestones in Indonesia beginning from the colonial era to the era of reformation is necessarily a guide to succeeding generations. As the first president of Indonesia, Soekarno would advice "never leave history". The youth are strategic targets in expanding understanding of agrarian reform. Thus, as an effort to advance agrarian reform implementation, it requires in-depth study related to the history and dynamics of agrarian policy especially as a basic agenda in the context of transforming agrarian reform as the needed basic agenda in building the nation.

Specific studies on the history of agrarian, agrarian policies and agrarian reforms have not been fully implemented; meanwhile, the agrarian reforms implementation is one of the difficult things to meet by people without having strong agrarian awareness. This has implications for the limited knowledge, which implies that the society often time is trapped in their ignorance of the right to access agrarian resources. What is the 
agrarian history as an agrarian policy milestone in Indonesia? What is the dynamics of agrarian policy as a leading factor to agrarian reform? and How is agrarian policy as a means of transforming agrarian reform in Indonesia?.

Based on those elaborated problems, it is quite strategic to study the history and dynamics of agrarian policy in the 1602-2016 era in the context of agrarian reform transformation in Indonesia.

\section{RESEARCH METHODS}

This study was conducted using normative legal research methods (Soerjono Soekanto et al., 2009: 13-14), which used document studies from library sources, among others are the primary legal sources of statutory regulations, secondary legal sources taken from opinions of the agrarian law experts, and tertiary legal sources of various studies from various literature books and campuses. This research was conducted to obtain the objective legal data (legal norms), and subjective legal data (Hardijan Rusli, 2006: 50). This study used a historical approach (Peter Mahmud Marzuki, 2009: 93), by examining various regulations and policies related to agrarian law, various problems and analysis related to their application. This research was designed with qualitative research model, which is scientifically, in normally situated environment conducted data mining or netting phenomena towards the elaborated problems being studied (Lincoln \& Guba, 1985: 97). This research applied a conjunctural approach which, according to Stuart Hall, is "a complex, historically specific, domain of a crisis affecting" $(1988,127)$, primary used to refer the dynamic configuration and interaction between forces in the present, in which various political tactics. As Grossberg argues, analyze when, how and in what situations the conjuncture moves from one round to the next, and achieves "a balance between the old and the new" (Rachman, 2012). This study was carried out in collaboration with The Indo Strategy Foundation (TISF) in Jakarta which has conducted a public policy study on agrarian reform. The research subjects are literary texts, historical testimonies and opinions of agrarian experts and organizations focused on the agrarian reform issues.

\section{DISCUSSION AND RESEARCH RESULT}

\section{A. Agrarian History as a Milestone of the Agrarian Policy}

Historical milestones need to be inculcated to people, especially for today's young generation. In case the youth do not know the history of their own people, the nation confronts serious problems, more specifically the loss of character. Among the countries which have agrarian characteristics such as Indonesia, the agrarian policies need to be implemented, and to organize agrarian resources in 
order to bring benefits to the greatest prosperity of the people and be able to be preserved for future generations (sustainability).

Agrarian history begins from the colonial era, agrarian struggle in the era of national movements, beginning from Soekarno era to the post-independence era and to Basic Agrarian Law (UUPA) establishment, these were the path to preparing the national agrarian policies. Soekarno underlined that, "Independence is a golden bridge, across that bridge will be perfected we have a society". Soekarno once delivered his speech on June 1, 1945, which is a momentum after Indonesia declared its independence to immediately do transformation to eliminate the economic featured with feudalism, capitalism and imperialism. The economic transformation style follows the Pancasila economic model as manifested in Article 33 of the 1945 of the Republic of Indonesia Constitution. The spirit was then formulated into the UUPA 1960 which was ratified on September 24, 1960 by deliberation of DPR. This law is an important part of the Indonesian revolution to create a just and prosperous society, through the implementation of agrarian reform.

The way to realize the ideals of the Proclamation is to complete the agrarian reform agenda with all efforts to eradicate the existing capitalism, feudalism and imperialism in the country in the colonial era. The spirit of negating the economic style of colonial heritage was realized by the agenda of structuring the ownership structure, control and management of agrarian resources, especially land. Therefore, a serious study is needed to strengthen people's awareness thorough careful understanding about the history regarding the agrarian conflicts and agrarian policies in Indonesia.

The implementation of agrarian policy in its development experiences dynamics much of which was influenced by agrarian history. Agrarian history need to be photographed, thus each lesson is learnable for policy makers in every era of leadership. Agrarian History in Indonesia is divided into the following periods:

\section{Agrarian History in the Colonial Era (before 1945)}

\section{a. Prior to Wet Agriculture (1870)}

The depart of VOC into Indonesia in 1602 monopolized the forced planting system and sold land to the private, thus many parties new landowners and private control of the population were merging. However, in 1799 the VOC was dissolved by the Netherlands Indies Government due to bankruptcy and its authority became under the Dutch Indies Government. The Dutch East Indies government, Raffles the Governor-General implemented a tax collection system in the form 
of money and land harvests to the people and the applied land leases to farmers by the Dutch authority.

The various taxes enacted by the Dutch made people's lives especially in Java highly pathetic. Therefore, in 1825 until 1830 the Diponegoro war broke out as a form of rebellion against the Dutch Colonial Government which had afflicted the lives of the Indonesian people at that time. Among the enacted taxes include: land tax, "Pengawang-awang" tax (house yard), Pacumpleng (hoouse) tax, "Wilah-wilih" (rice field) tax, "Pajongkte" tax (moving house).

In 1830, the Governor General Johnnes Van Den Bosch abolished the land rent system. The Cultivation System was enforced more forcefully (cultuurstelsel). This policy united the system of compulsory surrender and land tax. His distinctive feature was the compulsory surrendering the agricultural products, not in money form.

In 1848 the liberal group won a victory in the Netherlands, which could eventually change the Dutch Constitution, the amended provisions stated that the colonial government must be guided by regulations. In 1854 a law called Regerings Regulation (RR) was issued, in article 62 which stated that the Governor-General gave permission to lease land under the terms and conditions stipulated in the regulations.

In 1865, the agrarian sectoralism began, with a law governing forestry that was firstly issued and perpetuated the principle of state power (the Netherlands) or state domain and became the basis for the birth of Agrarische Wet 1870.

In 1870 the issuance of the Dutch Colonial Agrarian Law (Agrarische Wet) was the basis for accumulating capital from the European companies investing in the Dutch East Indies (now Indonesia) by opening plantations for export commodities.

Agrarische Wet 1870 states that, all land (including forests) for which there is no claim of absolute rights (eigendom) is the domain controlled by the State or Domein Verklaring. As a result, private companies can control large-scale plantations in Indonesia. Erpacht rights (now HGU) are granted for a maximum of 75 years to the private sector.

\section{b. The period after Agraris Wet (1870 to the proclamation of independence).}

For approximately 16 years the Agrarische Wet 1870 took effect, many revolts emerged from farmers in Indonesia, including the Ciemas peasant uprising (1886), Cilegon Banten peasant uprising (1888), 
Entong Gendut (1916), peasant uprisings in Semarang (Caping Koprak), Palembang (Sarekat Abang), Jambi (Pemberontakan Gelambit), and the Cimareme incident (1919). Those rebellion were born because, the Agrarische Wet 1870 was stood for the colonial government's internet, which was conflicted to people's interest.

Bearing such suffering afflicted by the Indonesian people at that day, beginning in 1928, a national movement was born to fight against the invaders, including in combating against the practice of imperialism and the suppression of colonialism. There emerged Political awareness known as "Ethical Politics" that the Netherlands owed the natural wealth from the Indonesian people that had been taken forcefully, therefore, all of those needed to be exchanged with education, emigration and irrigation to create people's welfare. The Governor-general Van Hentz established people's credit banks, village granaries and pawnshops. At this time there were special arrangements of private lands and recognition of the residents' rights over their land, ie., for residents of individual's rights to generations over the private land, residents were also entitled to land plots.

In 1930, Soekarno dismantled the practice of imperialism and the suppression of colonialism in terms of agrarianism and excess capital surpluses which the Dutch and Europe absorbed from the land and power of the Indonesian people. He delivered this harsh description before the Dutch East Indies colonial court in Bandung, August 18, 1930.

In 1942 the Japanese took control over Indonesia; the people were forced to work and handed over their work, food and agricultural products to the Japanese invaders for the availability of Japanese fascist military food. This era was the moment the Indonesian people were forced to work as Romusha (forced labor) without getting paid. The people continued to pay land rent, and work hard on land owned by landlords (cf.Nakamura, 1970). The Japanese occupation led to a peasant uprising, among others in June 1942 there was the Aron (Uaron) peasant uprising in Pancur Batu, Deli Serdang, North Sumatra and in November 1942 there was a peasant uprising in Cut Pilieng, Aceh. On October 23, 1943 there was a peasant uprising in Karangampel, Indramayu and in November to December 1943 there was in Lohbener, Indramayu. In February 1944 there was a peasant uprising in the pesantren Sukamanah, Singaparna, and a Meureudu and Beureum peasant rebellion, Aceh in November 1944. In May 1945 there was Dayak peasant revolt of the Tajan and Ketapang Dayak tribes, Kalimantan. 


\section{History of Agrarian Reform after the Proclamation of Independence}

The President Soekarno on June 1, 1945 delivered a speech before the BPUPK session known as the Speech of the Birth of the Pancasila. Bung Karno offered five basic principles of Indonesian Independence, namely: Nationality, Internationalism / Humanity, Consensus or Democracy, Social Welfare and the Divinity. The principle of Democracy and Social Welfare is called Socio-Democracy (a combination between political and economic democracy) which is a principle for the struggle for agrarian justice in an independent Indonesia.

In February 1946, the Vice President Hatta in his speech argued that as an agrarian country, agriculture should be the basis of development. Some important principles: (1) no land can be used as an instrument of power; (2) a very large amount of land owned by someone is against the principle of justice in the economy; (3) extensive land uses are regulated according to cooperatives with government supervision; (4) land according to customary law belongs to the society; (5) land can be cultivated and become the property of individuals if it is not extensive and not for profit; and (6) vacant land can be cultivated as a source of people's prosperity.

Furthermore, the Law Number 1 of 1958 asserts that all rights and privileges owned by private landlords were abolished by the government. Then Bung Karno in his speech "(Rediscovery of Our RevolutionThe Rediscovery of Our Revolution)" on August 17, 1959, stated "we inherited land issues, from the Netherlands, including eigendom rights. We cannot justify that in an independent Indonesia, there is a plot of land that is deemed to be endangered by foreigners. We only know the right of land ownership for the people of Indonesia, in accordance with article 33 of the 1945 Constitution. "

Bung Karno's speech on August 17, 1960 concerning" Like an Angel Who Invaded from the Sky of the Path of Our Revolution "states" The Indonesian Revolution without Land Reform is an absolute Indonesian Revolution. ... Land reform means the abolition of all foreign rights and colonial concessions on land, and ending feudal exploitation gradually on the other hand Land reform means strengthening and expanding land ownership for all Indonesian people, especially the peasants.

Finally, September 24 1960, the Law Number 5 of 1960 concerning Basic Regulations on Agrarian Principles (UUPA) was legalized as a national agrarian law for the Indonesian people. The purpose of the UUPA is to lay the foundations for the drafting of national agrarian law, to establish unity 
and simplicity in national land law and provide legal certainty regarding land rights for all citizens.

From such description above, that agrarian history is an important part of the process of realizing the agrarian policy, beginning from the era of Dutch colonialism which was identical with the agrarian resources exploitation to the emergence of peasant resistance against imperialism, this condition consequently rose to the spirit of national movement and the issuance of Law Number 5 of 1960 concerning Basic Rules on Agrarian Principles, as the basis for the birth of national agrarian policies in Indonesia.

\section{The Dynamics of Agrarian Policy As a Priority in Agrarian Reform}

The restructuring of agrarian resources through agrarian reform aims to create a prosperous society, and have awareness in using and maintaining of the agrarian resources. Agrarian policy is an important part of the process of realizing agrarian reform, especially in dealing with the agrarian conflicts in Indonesia. However, agrarian conflicts often time occur as a result of policies which have conflicting interest against the principles of agrarian reform, leading losses to the people.

The following is an explanation of the dynamics of agrarian policies issued by the government after the birth of the Basic Agrarian Law (UUPA) of 1960, which shows the emerged various policy analyzes underlying the reasons on the importance of agrarian reform being a policy concern in Indonesia.

\section{a. Agrarian Policy after Undang-Undang Pokok Agraria (UUPA)}

After the UUP was legitimated, government issued regulations to carry out land reform as the policies realization in Soekarno's era that sought to strengthen land rights for the people. At the time, several regulations were issued, including Law Number 1 of 1958 concerning the Elimination of Particle Land, Law Number 2 of 1960 concerning Revenue Sharing, and Law Number 56 of 1960 concerning the Determination of Agricultural Land Area.

On January 19, 1961 Dewan Pertimbangan Agung (DPA) the Supreme Advisory Council issued a decision regarding the Details of Guidelines for implementing the Political Manifesto of the Republic of Indonesia with Number 1 / Kpts / Sd / I / 61 which decided the details of "The Way of Our Revolution" as follows: Part I. Preambule (I) Affirmation of the Various Basic Aspects of the Indonesian Revolution: (1) The Nature of Each Revolution; (2) The Indonesian Revolution is Part of the World Revolution; (3) One Leader and One Conception 
of Revolution; (4) Land reform is an Absolute Part of the Indonesian Revolution. (II) Affirmation of Ways to Implement Manipol: (1) Mutual Cooperation; (2) National Front; (3) Retooling; (4) West Irian; (5) Security; (6) Foreign Policy; (7) Enhancing Civilization and Manipol indoctrination; (8) Land for Farmers; (9) Implementing.

Soekarno subsequently issued Government Regulation Number 10 of 1961 concerning the Land Registration, and Government Regulation Number 224 of 1961 concerning the Implementation of Land Distribution and Compensation. In the process of compensation for farmers and fishermen making deposits at the Cooperative Bank by $10 \%$, the rest of the compensation would be returned as landform reforms.

In 1964, a court committee land reform was established through Presidential Decree in 1964. On 31 October 1964, to solve the problem of land reform standpoint from legal perspective, Soekarno's Government issued Law Number 21 of 1964 concerning the Land Justice Reform. However, the land reform policy during Soekarno's era or known as the Old Order era had not been carried out properly. This is due to the lack of sincere willingness from the government and political support in implementing land reform, in addition to the unavailability of data and information as well as financing interests, which become obstacles in compiling the needs to realize the land reform program. This condition triggered the constantly emerging of various agrarian problems, especially the certainty of land rights and justice in land tenure which had always been in conflict with people's interest.

Furthermore, the agrarian policy existed in the New Order era (ORBA) after President Soekarno's reign, which was the President Soeharto's era. In the New Order era, it turns out that agrarian policies had not yet been able to implement the objectives of land reform, this is indicated by the Foreign Investment Law (Law No. 1 of 1967), which provided an opportunity for foreign investors to control agrarian resources. One of the results was the signing of the Freeport contract agreement covering an area of 10,000 ha for 30 years. Then, the Law Number 1967 on Forestry was legitimated, which seemed to revive the dominion of domklaring the colonial era, since those who could not show proof of people's ownership could lose their land.

Furthermore, during the ORBA, the government established the Agrarian Reform Authority Agency (BORA), which function was to 1) coordinating all sectors to carry out agrarian reform; 2) accelerating 
the process of implementing the agrarian reform; and 3) dealing with agrarian conflicts.

Presidential Decree Number 32 of 1979 concerning the Principles of Policy for Granting New Rights to Original Land. Conversion of Western Rights regulates the transfer of western rights, especially for ex-Dutch estates, for 20 years since 1960 and Minister of Home Affairs Regulation No. 3 of 1979 concerning Provisions concerning Application and Granting of New Rights on Land Origin of Conversion of Western Rights. Unfortunately, the land return had never happened, since most of the plantations had been nationalized and turned into BUMN.

During the ORBA there was a Green Revolution policy, which emphasized increasing production through adopting the capital-intensive technology, which consequently neglect environment health. This resulted in changes - the process of land tenure and income disparities in the villages. In 1988 the State Land Agency Badan Pertanahan Negara (BPN) was established with as orderly land chess.

\section{b. Agrarian Policy in the Era of Reformation}

Agrarian policy in the reform era began during the administration of President BJ Habibie, which issued Presidential Decree No. 48 of 1999 concerning the Policy and Regulatory Study Team in the context of Landreform Implementation. Another policy was issued in Law No. 41 on Forestry, on September 30, 1999, which in its application was often a source of agrarian conflict, since it led the agrarian fighters caught into prison.

Subsequently in Gus Dur era, on 20 October 1999 a controversial statement was issued, that $40 \%$ of plantation land originating from society land was stolen by the plantations. Plantation land, specifically state property, originated from Dutch colonial era plantations with Domein Verklaring system.

In the era of Megawati Soekarno Putri, the agrarian policy was further emphasized by the issuance of TAP MPR Number IX of 2001 concerning the Agrarian Reform and Natural Resource Management, which encouraged the implementation of agrarian reform. The contents of the MPR Decree are to order the President and the Parliament to revoke laws and regulations that are contrary to the implementation of agrarian reform. All forms of agrarian reform implementation agenda, the President must report to the MPR Annual Session. 
Furthermore, in the era of Susilo Bambang Yudoyono, various agrarian movements grew up, including Federasi Serikat Petani Indonesia (FSPI) 'the Federation of Indonesian Peasant Union' which later changed its name Aliansi Gerakan Reforma Agraria to Aliansi Petani Indoensia (API) 'the Indonesian Peasant Alliance', Aliansi Gerakan Reforma Agraria (AGRA) 'the Indonesian Peasant Union', the Peasant Union at the national level carried agrarian reform. However, on August 11, 2004 the Law Number 18 of 2004 concerning Plantations was legitimated, which became an entry point for investors to open large scale plantations. (Article 21 and article 47 paragraph 1 and paragraph 2, on September 19, 2011 was canceled by the Constitutional Court). Subsequently, the Law Number 25 of 2007 concerning Investment was legitimated, which tended to provide a form of liberalization in Indonesia (Primayanti \& Fedryansyah, 2019).

As an effort to resolve the occurred conflict, in other words, a step forward, on June 30, 2004 the National Human Rights Commission established the Manuscript Formation of the National Commission for Settlement of Agrarian Conflict (KNuPKA). This paper is the result of advocacy and proposal of the Agrarian Reform Consortium (KPA) along with the other civil society organizations and agrarian experts.

On October 14, 2009, the Law Number 41 of 2009 concerning Protection of Sustainable Food Land Farms was legitimated, which restrained the rate of conversion of agricultural land to non-agricultural land. On January 22, 2010, the Republic of Indonesia Government Regulation No. 11 of 2010 concerning the Control and Utilization of the Abandoned Land, this regulation was intended to bring order and increase economic value of the abandoned lands.

Furthermore, the Larasita policy was legitimated; which in fact, it led to the liberalization of the lands in Indonesia. Actually, this policy is claimed as a groundbreaking mobile office to certify society land to villages. However, what happens was that if land certification practices inequality, the agrarian structure (ownership, control and land use) would actually legalize the unequal structure. The certification process through Larasita, which was not preceded by agrarian reform, tended to create a liberal land market which was strongly in contrary to the Basic Agrarian Law 1960. Since there were imbalances in land ownership and control by the people, while there were few people and business entities that controlled large tracts of land. Then the bias side of this was the certification which legalizes the inequality. 
On January 14, 2012, the Law Number 2 of 2012 concerning the Land Procurement for Development in the Public Interest was legitimated. Furthermore, the Presidential Regulation No. 71 of 2012 concerning the Provision of Land for Development in the Public Interest was legitimated. Through the birth of this policy, the more widespread the acquisition of land for the benefit of infrastructure development and investment would be smoother and faster implemented.

The alignments for agrarian affairs began to appear in the era of President Joko Widodo (Jokowi) leadership, on October 26, 2014 the Ministry of Agriculture and Spatial Planning was established, the purpose of establishing this ministry was to resolve the possible agrarian conflicts. Furthermore, on April 13, 2016 the Ministry of Agrarian Affairs and Spatial Planning / National Land Agency submitted 383 hectares of land and 1,250 certificates to Badega, Garut, West Java farmers, who had been fighting for 498 ha of land since the Japanese era. On December 30, 2016 President Jokowi submitted the Decree of Recognition of Indigenous Forests to nine (9) indigenous peoples and divided the land area of 12,000 ha. It is planned that Jokowi Era will distribute 12.7 million hectares of forest to the society, both farmers and indigenous peoples. The government also planned to distribute land certificates to the people of 4.5 million hectares. Certification is part of land legalization. The government is targeting 9 million ha of land to be certified by 2019. An area of 0.6 million hectares of land is transmigration land that has not been certified. The remaining 3.9 million hectares are from the society land assets legalization. Meanwhile for land redistribution, which is 0.4 million ha of HGU land and abandoned, and 4.1 million ha of land from the release of forest area. Furthermore, the Ministry of Environment and Forestry issued Ministerial Regulation Number P.83 / MENLHK / SETJEN / KUM.1 / 10/2016 concerning the Social Forestry which regulates society-related access to forests and agrarian resources in it by giving people access to utilize a piece of land in forest area within a certain period of time, ie for 35 years with evaluations carried out every five years. The government is targeting 12.7 million ha of forested land that is the object of social forestry. Indicative Map of the Social Forestry Area (PIAPS) has been prepared by the Ministry of Environment and Forestry and is spread almost in all provinces, including in the Perhutani working area. However, specifically for Social Forestry in the Perhutani region, there is a Ministerial Regulation that specifically regulates, namely Ministerial Regulation Number P.39 / MENLHK / 
SETJEN / KUM.1 / 6/2017 concerning Social Forestry in the Perhutani Housing Area. The Ministerial Regulation regulates the use of land in the Perhutani working area and the net profit sharing system between the cultivators and Perhutani. Some of the achievements of the social forestry to September 2017 that it has reached 1,053,477 ha, specifically for Social Forestry in the Perhutani region, it has not been effectively implemented, there have even been rejections from farmer organizations, those which are in conflict with the Perhutani.

Based on the agrarian policy studies after the UUPA enactment of 1960 , there have been various rules governing the agrarian affairs in Indonesia. However, the various policies were not all oriented towards the objectives of the UUP, even in dynamics they often led to problems in their implementation, including:

1) The agrarian policies which do not go along with the principles of justice and people's welfare, instead it produces gaps in land tenure

2) Lack of certainty of the land rights in controlling land, since the owners of capital is more prefer instead of people.

3) Increasing the openness of the foreign investors to control agrarian resources, this further leads to liberalization in Indonesia.

4) The designations of forest area, thus many people were driven from their land.

5) Nationalization of plantations through BUMN.

6) Repressive resolution of agrarian conflicts.

7) Certification of land tenure and land use that would actually legalize the unequal structure in people's ownership and control over land,

8) Land acquisition in the process of land acquisition for infrastructure.

9) Lack of society involvement, especially farmer organizations in the agrarian conflicts resolution

10) Lack of data, information and financial support in preparing the needs and realization of agrarian policies.

Understanding the dynamics of agrarian policies across regimes is also a matter of providing wisdom, a lesson that policymakers no longer exacerbate agrarian problems and repeat the bad historical legacy in agrarian management. The agrarian policy is an important part of the process of realizing agrarian reform, especially in dealing with agrarian problems or conflicts in Indonesia. The rearrangement of agrarian resources through agrarian reform policies aims to reform the agrarian resources to help people achieve their justice and prosperity. 


\section{The Agrarian Policy in the context of Transforming the Agrarian Reform}

Soekarno asserted that, "Independence is a golden bridge, across from that bridge will be perfected we have a society". Bung Karno's will was conveyed again during the Speech of the birth of Pancasila, at the BPUPK session on June 1, 1945. The momentum of post-independence Indonesia was immediately changed to negate the economic features of feudalism, capitalism and imperialism. The transformation form is directed towards the Pancasila economy model, which is manifested in Article 33 of the 1945 Constitution of the Republic of Indonesia. The law is intended to create a just and prosperous society, through the implementation of agrarian reform.

The nation's founders realized that to realize the ideals of the Proclamation was to complete the agrarian reform agenda with all efforts to eradicate feudalism, capitalism and imperialism that were firmly planted in the country in the colonial era. The spirit of negating the economic model of colonial heritage was realized through the agenda of overhauling the structure of ownership, control and management of natural resources (agrarian), especially the land.

Land reform is a redistribution of land tenure and use or, more broadly, natural resources, it aims to realize people's welfare, where in reality it cannot always run smoothly, and potentially may fail without having supported by adequate facilities and infrastructure. Land reform in addition to facilities and infrastructure are the so called agrarian reform. Gunawan Wiradi called it "land reform plus".

Many people think that land reform is a communist idea, even though such idea may not be true. Land reform as an effort to improve people's welfare began 594 years before Christ by a Greek king named Solon and continued by Cleisthenes. According to Mansour Fakih (Irwan Nirwana, et al, 2003: 4) Land reform is a policy to prevent social chaos and solve the problem of political and economic crisis. Initially, land reform was a reform of the system of land ownership or redistribution of land ownership rights. However, its development has been expanded not only with regard to agricultural land and development, but more specifically with regard to improving land tenure systems, cropping patterns, scale of agricultural operations, land ownership, agricultural credit institutions, marketing and agricultural extension, even agricultural technology. Nowadays land reform is popularly called Agrarian Reform.

Agrarian reform is a state political agenda which aimed at improving the people's welfare, through restructuring the land tenure, ownership, use 
and utilization (land reform) that takes into account land ownership for the people's sake, especially farmers.

As the results of the agrarian history study, the agrarian reform has been initially used since the enactment of UUPA 1960, hereinafter referred to as Undang-Undang Pokok Agraria (UUPA). Article 1 paragraph (1) states that, "all land within the territory of the State of Indonesia is the common land of all Indonesian people". Land becomes an important resource for an agrarian country, for its sustainability will affect the national resilience condition, especially in welfare objective. Indonesia as an agrarian country has realized the importance of land to meet the people's needs and prosperity in accordance with the Pancasila and the NRI Constitution Article 33 paragraph 3 .

As a basis in realizing the state goals of agrarian policy in the context of agrarian reform should be relevant to Pancasila values, the NRI Constitution of 1945 and the Basic Agrarian Law as the main regulations which applicable to various implementing regulations.

Agrarian policy must be based on Pancasila, especially applying the manifested values. Furthermore, in UUPA on the consideration part letter c, states that "National agrarian law must realize the incarnation of God Almighty, Humanity, Nationality, Society and Social Justice as the principle of state spirituality and the ideals of the nation".

The results of this study note that the Pancasila values embodiment reflected in the Articles of UUPA are as follows:

1) Divinity Value illustrates that the Indonesian people believe in a God who has a religion and belief. Divinity value is manifested in UUPA article 1 number 2 that "All earth, water and space, including natural resources in the territory of the Republic of Indonesia as a gift from the God Almighty".

2) Humanity Value, is the recognition and respect for the rights of others / fellow human beings dignity, helping each other, and acting as civilized human beings. This value manifested in UUPA is in the article 5 which reads "Agrarian Law that applies on earth, water and space is customary law, as long as it does not conflict with national and state interests". This article concludes that UUPA recognizes the plurality of rules related to agrarian which had already been existed in the society.

3) The Unity Value, it says that the Indonesian people must uphold the unity, one does not discriminate against each other. The Indonesian people place unity, willingly put the nation and state's interests ahead of 
personal and group's interests. This value in the UUPA is implemented in:

a) Article 6, which reads "All land rights have a social function, what is meant by a social function even though the land is privately owned but must be beneficial to the welfare and security that has it and also benefit the society and the State" ;

b) Article 7 which reads, "In order not to harm the public interest, ownership and control of land that exceeds the limit is not permitted". This article implies that land ownership must pay attention to or prioritize the public interest.

c) Article 18 which reads, "For the public interest including the interests of the nation and the State and the common interests of the people, land rights can be revoked, by providing appropriate compensation and in the manner stipulated by law".

4) People's Value, means that everyone shares the same right in terms of the position, rights and obligations, through consultation and mutual cooperation, this value is inspired from the fourth state's principle. In UUPA this value is implemented in the article 12 number 1, "All joint efforts in the agrarian field are based on shared interests in the framework of national interests, in the form of cooperatives or other forms of mutual assistance.

5) The Social Justice Value, means that the social life justice must encompass all the people of Indonesia, equality of rights in various respects based on the rights and obligations of each person, and attitudes of mutual respect for others to achieve the justice. The embodiment of this value in the UUPA refers to the article 13 which reads,

a) the Government attempts to make efforts in the agrarian field regulated to increase the production and prosperity of the people as referred to in article 2 paragraph (3);

b) The government prevents businesses in the agrarian field from various private monopoly organizations and individuals;

c) Government efforts in the agrarian field that are monopolistic can only be carried out by law;

d) The government is trying to advance social security and assurance including in the labor sector in efforts on the agrarian field.

Furthermore, based on the Decree of the People's Consultative Assembly Number IX of 2001 Concerning the Agrarian Reform and Management of Natural Resources in Article 2 which states that agrarian reform includes a 
continuous process regarding the restructuring of the control, ownership, use, and utilization of agrarian resources, carried out to achieve legal certainty and protection as well as justice and prosperity for all the Indonesian people.

Agrarian resource management as part of the natural resources can be realized by encouraging the agrarian resource management policy reforms based on the development paradigm from the growth to environmental management, and transforming the agrarian reforms. According to Wiradi (cf.J. Harriss 1982, cited in Wiradi, 2009: 96-97), the transformation of agrarian reform for an agrarian country is important to do to realize the structure of society in which agriculture is no longer exclusive but integrated into other economic pillars nationally, more productive, and people's welfare increases..

Agrarian Reform refers to a broader and comprehensive understanding, since it involves various supporting programs that can affect the agricultural sector performance after land redistribution. Agrarian reform doe not distribute land and title certificates, however, it redistributes land tenure and use along with the infrastructure, and supporting policies such as exportimport, foreign debt, investment, price stabilization and security agencies, all of which are integrated with each other. Without this, the agrarian reform shall not be succeeded.

Agrarian reform according to Iwan Nurdin from the National Council for Agrarian Reform Consortium (KPA), suggests that the existence of agrarian reform, especially in rural areas, aims to advance, be fair and independent. The transformation of agrarian reform lies in the arrangement of agrarian resources as an effort to eliminate the gaps in the control over land rights and change the pattern of agricultural life to be more productive and sustainable. Actually, the agrarian reform is implemented through the efforts of asset reform and access reform. Asset reform is carried out through land redistribution program that results the land rights for farmers, thus it enables farmers to have power over their lands. Whereas access reform concerns the asset reform post-activity, which is how to manage land that has been obtained by farmers, both by providing education, training and assistance in facilities and infrastructure that support productive agricultural activities integrated with the economic pillars to improve farmers' welfare.

Transformation in the agrarian reform concept refers to the formation of an 'agrarian' structure of society that is integrated into the economic pillars to improve welfare. For this reason it is important to strive for a process of society change which previously only tended to only carry out traditional agricultural activities towards a more orderly way of life for all farmers. 
Efforts to transform the agrarian reform concept towards policies of oriented towards asset reform and access to reform are needed. Asset reform is highly needed to provide people's rights certainty in cultivating the land. Through the certainty of these rights, it enables the recipient of the asset to benefit and use it. Furthermore, there is a need to ensure the sustainability of benefits received by the recipient of land redistribution rights through developing the appropriate access reforms.

In implementing agrarian reform, a comprehensive transformation of the national agrarian policy from the government and technical stages is needed in order that the program can properly work. This means that the agrarian reform program is not a land redistribution program, but rather a program that must be supported from infrastructure, investment policies to security. Some stages to be carried out are:

1) The agrarian data availability

a) Providing map of land tenure and use, i.e., holders of land rights, land area and utilization, land designation;

b) Determining the redistribution of abandoned, excess and absentee lands

c) Examining soil data in terms of the height / contour, suitability, soil structure, rainfall, humidity of the lands.

2) Establishing a special agrarian court

This is intended to quickly resolve the problem in case a land dispute occurs due to the program. This special court is established in every city / regency, however, the most important thing is that the making of such court should be inspired from the Article 33 of the 1945 Constitution, which is "the earth, water and wealth contained within it is controlled by the state and used for the greatest prosperity of the people".

3) Establishing Land for Objects Redistribution / Land for Agrarian Reform Objects

This stage determines how much land will be distributed to farm families / cooperatives with which they can improve their welfare. In addition, in this stage the land areas to be used for agricultural land and integrated planning include irrigation, superior seeds, fertilizers, pesticides, fodder, counseling, banks, environmental sustainability and security have begun. The agrarian reform program is not only limited to the distribution of land to the people, however, it should be sustained by supporting infrastructure as above. 
4) Establishing Land Recipient Farmers

The agrarian reform program is implemented on the principle of "land for tenants", therefore, the land rights holders are obliged to work on the land themselves. The rights holders are prohibited from renting, contracting, mortgaging, collecting, or paying others as agricultural laborers. The land is granted with rights for them to work on, and remains their right as long as they fulfill their obligations as a cultivator. This right will expire if within six months they do not work on their land. At this stage, a number of steps will be taken to acquire land - farmers or cooperatives including the registration of prospective farmers and evaluation to ensure their readiness and feasibility. However, in case there are prospective farmers who do not meet the criteria enacted by the government, they must distribute them in other forms of business, to supporting production or processing industries, such as making / maintaining irrigation, producing superior seeds, fertilizers, and pesticides.

5) Conducting Land Redistribution

After having determined the land recipients, at this stage the land will be redistributed to potential farmers or cooperatives. Land redistributed as large as the farmer can work on. family or cooperative. This redistribution of land is prioritized to homeless farmers, smallholders, and other poor farmers who live around the land. However, what should be emphasized here, that the rights granted to farmers for the land are not ownership rights, but the rights to work on that can be extended continuously as long as the farmers are working on their land.

6) Supporting Programs

a) Pre-supporting facilities such as land-clearing, land-treatment, infrastructure, irrigation, agricultural education, provision of agricultural equipment, superior seeds, fertilizers, pesticides, village banks;

b) Crop production and processing of agricultural or food products;

c) Marketing of products guaranteed by the state through the National Logistics Agency;

d) Exporting and importing policies;

e) Tightening of foreign investment;

Transformation in the agrarian reform concept refers to the formation of an 'agrarian' structure of society integrated into the economic pillars to improve people's welfare. For this reason it is important to strive for an agrarian policy oriented towards agrarian reform to a more prosperous life order for the greatest prosperity of the people. 


\section{CONCLUSION}

There will emerge serious problem when the young generations do not have a complete understanding towards the history of their own predecessors, beginning from the struggle against colonialism, invaders, agrarian era, national movement, Soekarno's land reform policy to the post-reform era. The dynamics of agrarian history are an important part of the policy realization process, especially in dealing with agrarian conflicts in Indonesia.

Understanding agrarian milestones starting from crossing agrarian policies in various areas leadership provides lessons, and evaluations that policy makers no longer exacerbate agrarian problems and repeat the bad historical legacy in agrarian management. All of this is the dynamics of agrarian politics, each era has its own view of seeing the agrarian development.

The agrarian reform agenda will remain a long debate. The problem lies on us, either we wish to solve it or we eliminate it for the agrarian reform has been going on for the past four centuries. In case we wish to solve it, we will take part in breaking the chain of the prolonged agrarian conflicts and inherited one gold ink to the next generation. However, if we wish to let it be by making the patchwork of agrarian conflicts an agrarian reform agenda claim, then we are bequeathing the problem of the past four centuries to the next generation and opening up opportunities for agrarian conflicts.

Transforming agrarian reform into a strategy in restructuring agrarian resources through agrarian reform policies will create a just and prosperous society in the using and maintaining the agrarian resources for the greatest prosperity of the Indonesian people.

\section{BIBLIOGRAPHY:}

\section{Books:}

Irwan Nirwana, et al. (2003). Landreform in the Village: Education and Organizing Guidance Series, Jakarta (Landreform di Desa: Seri Panduan Pendidikan dan Pengorganisasian, Jakarta), REaDBook (member of INSIST)

Lincoln, YS and Guba. (1985). Naturalistic Inquiry. Beverly Hills CA : Sage Publication Ins.

Peter Mahmud Marzuki. (2009). Legal Research (Penelitian Hukum), Jakarta : Kencana Prenada Media Group 
Rachman, Noer Fauzi. (2012). Landreform from time to time (Landreform dari masa ke masa). Yogyakarta: STPN and Sayogyo Institute.

Riyanto. Astim. (2009). Capita Selekta Constitutional Law (Kapita Selekta Hukum Konstitusi). Bandung : YAPEMDO

Wiradi, Gunawan. (2000). Agrarian Reform An Unending Journey (Reforma Agraria Perjalanan Yang Belum Berakhir), Cetakan pertama, Yogyakarta : INSISTPress.

Wiradi, Gunawan. (2003). Short writing, as "Introduction", in the "Discussion About Land Reform, Micro Credit, and World Bank (Tulisan ringkas, sebagai "Pengantar", dalam acara "Diskusi Tentang Landreform, Kredit Mikro, dan Bank Dunia”), diselenggarakan oleh LP3ES, di Jakarta, tanggal 7 Agustus 2003.

Wiradi, Gunawan. (2009). Matters of the Agrarian Problem: Agrarian Reform and Agrarian Research (Seluk Beluk Masalah Agraria: Reforma Agraria dan Penelitian Agraria). Yogyakarta.STPN Press dan Sajogyo Institute.

Wiradi, Gunawan. (2009). Agrarian Reform: An Unending Journey (Reforma Agraria: Perjalanan yang Belum Berakhir). Bogor: Sajogyo Institute.

Wiradi, Gunawan, et al. (2008). Two Ages of Land Tenure: The Pattern of Agricultural Land Tenure in Java from Time to Time (Dua Abad Penguasaan Tanah: Pola Penguasaan Tanah Pertanian di Jawa dari Masa ke Masa). Jakarta: Yayasan Obor.

Soekanto, Soerjono Soekanto, and Sri Mamudji. (2009). Normative Legal Research: A Short Review (Penelitian Hukum Normatif Suatu Tinjauan Singkat), Cetakan ke - 11, Jakarta : Raja Grafindo Persadal.

\section{Journals and Proceeding:}

Hadi Daryanto. (2014). Sekelumit Permasalahan Mendasar dalam Reforma Agraria dan Tata Kelola Hutan di Indonesia. Prosiding Seminar Hasil Penelitian Reforma Agraria untuk Mendukung Tata Kelola Kehutanan yang Baik, Jakarta : Pusat Litbang Perubahan Iklim dan Kebijakan Badan Penelitian dan Pengembangan Kehutanan Kementerian Kehutanan

Hardijan Rusli. (2006). Metode Penelitian Hukum Normatif: Bagaimana ?, Law Review, Volume V Number 3, Fakultas Hukum Universitas Pelita Harapan

Nakamura, M. General Imamura and the Early Period of Japanese Occupation, Indonesia, 10, (Oct., 1970), pp. 1-26, DOI: 10.2307/3350632https://www. jstor.org/stable/3350632

Primayanti, D. \& Fedryansyah. (2019). M. Konflik Agraria Antara Aliansi Gerakan Reforma Agraria (Agra) Pangalengan Dengan Perusahaan Daerah Agribisnis dan Pertambangan (PDAP), Jurnal kolaborasi Resolusi Konflik. 1, (1). 